\title{
A taxonomic outline of the Poecilimon affinis complex (Orthoptera) using the geometric morphometric approach
}

\author{
Maciej Kociński ${ }^{\text {Corresp., } 1}{ }^{\text {, Beata Grzywacz }}{ }^{1}$, Georgi Hristov ${ }^{2}$, Dragan Chobanov ${ }^{2}$ \\ 1 Institute of Systematics and Evolution of Animals, Polish Academy of Sciences, Kraków, Poland \\ 2 Institute of Biodiversity and Ecosystem Research, Bulgarian Academy of Sciences, Sofia, Bulgaria \\ Corresponding Author: Maciej Kociński \\ Email address: kocinski@isez.pan.krakow.pl
}

The genus Poecilimon contains 145 species, widely distributed in the Palaearctic, among which the Poecilimon ornatus group has the greatest diversity in the Balkans. Despite several revisions of the genus, the systematics of the species group, and in particular, of the taxa associated with the species Poecilimon affinis, is still unsolved. Due to morphological similarity, $P$. affinis with its subspecies, $P$. nonveilleri and $P$. pseudornatus form the Poecilimon affinis complex. The aim of this study is to test the hypotheses of an outlined species complex, namely the $P$. affinis complex, within the $P$. ornatus group using morphological data. Geometric analysis was conducted to explore variation in the structure of the tegmen, ovipositor, male cercus, and pronotum. A number of teeth and stridulatory file measurements provided additional information on morphological variation within the complex. A phylogenetic tree based on the cytochrome c oxidase subunit I gene (COI) was used for comparison with the morphological data. Canonical variate analysis showed that tegmen and male cercus are good morphostructures to distinguish the taxa belonging to the $P$. affinis complex from other species in the $P$. ornatus group. This may confirm our assumption for the designation of the $P$. affinis complex. The results of the principal component analysis of stridulatory file measurements, molecular data, and CVA of the ovipositor suggest adding two additional species to the complex: $P$. ornatus and $P$. hoelzeli. 


\section{A taxonomic outline of the Poecilimon affinis complex}

\section{2 (Orthoptera) using the geometric morphometric}

\section{3 approach}

5 Maciej Kociński $^{*}$, Beata Grzywacz ${ }^{1}$, Georgi Hristov², Dragan Chobanov²

$6 \quad{ }^{1}$ Institute of Systematics and Evolution of Animals, Polish Academy of Sciences, Kraków,

7 Poland

$8{ }^{2}$ Institute of Biodiversity and Ecosystem Research, Bulgarian Academy of Sciences, Sofia,

9 Bulgaria

$11 *$ Corresponding Author:

12 Maciej Kociński

13 Sławkowska 17, Kraków, 31-016, Poland

14 Email address: kocinski@isez.pan.krakow.pl

16 ORCID number:

17 Maciej Kociński: 0000-0002-6601-489X

18 Beata Grzywacz: 0000-0003-1222-8857

19 Georgi Hristov: 0000-0001-8330-6280

20 Dragan Chobanov: 0000-0002-1642-0363

21

22 Abstract 
23 The genus Poecilimon contains 145 species, widely distributed in the Palaearctic, among which

24 the Poecilimon ornatus group has the greatest diversity in the Balkans. Despite several revisions

25 of the genus, the systematics of the species group, and in particular, of the taxa associated with

26 the species Poecilimon affinis, is still unsolved. Due to morphological similarity, P. affinis with

27 its subspecies, $P$. nonveilleri and P. pseudornatus form the Poecilimon affinis complex. The aim

28 of this study is to test the hypotheses of an outlined species complex, namely the $P$. affinis

29 complex, within the P. ornatus group using morphological data. Geometric analysis was

30 conducted to explore variation in the structure of the tegmen, ovipositor, male cercus, and

31 pronotum. A number of teeth and stridulatory file measurements provided additional information

32 on morphological variation within the complex. A phylogenetic tree based on the cytochrome c

33 oxidase subunit I gene (COI) was used for comparison with the morphological data. Canonical

34 variate analysis showed that tegmen and male cercus are good morphostructures to distinguish

35 the taxa belonging to the $P$. affinis complex from other species in the $P$. ornatus group. This may

36 confirm our assumption for the designation of the $P$. affinis complex. The results of the principal

37 component analysis of stridulatory file measurements, molecular data, and CVA of the ovipositor

38 suggest adding two additional species to the complex: P. ornatus and P. hoelzeli.

40 Introduction

41 Poecilimon Fischer, 1853 is one of the most species-rich genera within the Phaneropterinae

42 subfamily. This genus comprises 145 species distributed in the Palearctic region (Cigliano et al.,

43 2021). All species are short-winged and flightless herbivorous bush-crickets with complex

44 acoustic behavior (Heller, 1990). Poecilimon is currently divided into 18 species groups based

45 on molecular, morphological and bioacoustic data, while 16 species are not assigned to any of 
46 them (Cigliano et al., 2021). The similarity and variability of morphological characteristics make

47 many Poecilimon species difficult to identify. Poecilimon ornatus group (13 species and 5

48 subspecies) (Fig. 1) is one of the groups for which the phylogenetic relationships between

49 species remain unclear and the status of several taxa is under discussion. Due to the reduced

50 wings and the influence of climatic and geomorphological factors, a rapid morphological

51 evolution took place in this group (Chobanov \& Heller, 2010).

52 The first revision of Poecilimon was conducted by Ramme (1933), who included taxa

53 from the currently recognized Poecilimon ornatus group in “Gruppe I." In 1984, Heller

54 suggested dividing the group into eight taxa (P. nobilis Brunner von Wattenwyl, 1878; P. obesus

55 obesus Brunner von Wattenwyl, 1878; P. obesus artedentatus Heller, 1984; P. affinis affinis

56 (Frivaldszky, 1867); P. affinis komareki Cejchan, 1957; P. affinis hoelzeli Harz, 1966; P. ornatus

57 (Schmidt, 1850) and P. pancici Karaman, 1958; distributed mainly in the Balkans). Later, $P$.

58 artedentatus and $P$. hoelzeli were given species status (Willemse, 1985; Willemse \& Heller,

59 1992), while $P$. pancici was synonymized (Willemse, 1985). Further, six new species were

60 described (P. pindos F. Willemse, 1982; P. soulion L. Willemse, 1987; P. gracilioides F.

61 Willemse \& Heller, 1992; P. jablanicensis Chobanov \& Heller, 2010; P. pseudornatus Ingrisch

62 \& Pavicevic, 2010; P. nonveilleri Ingrisch \& Pavicevic, 2010).

63 Among the $P$. ornatus group, $P$. affinis has the widest geographic range. It is distributed

64 from northern Greece to the Carpathians in Romania and an isolated spot in Ukraine. According

65 to Cigliano et al. (2021), P. affinis consists of five subspecies (P. affinis affinis (Frivaldszky,

66 1868); P. a. dinaricus Ingrisch \& Pavicevic, 2010; P. a. hajlensis Karaman, 1974; P. a. komareki

67 Cejchan, 1957; P. a. serbicus Karaman, 1974). Karaman (1974) reduced the status of P. poecilus

68 Ramme, 1951 to a subspecies of $P$. affinis and described two new subspecies: $P$. a. serbicus and 
69 P. a. hajlensis. In 1984, Heller suggested that P. poecilus and P. a. affinis are synonymous. Due

70 to doubts about the taxonomic status of $P$. poecilus, in the present study it will be treated

71 separately. Poecilimon komareki was described by Cejchan (1957), but Heller (1984) regarded it

72 as a subspecies of $P$. affinis because of their similarity. Karaman (1972) described P. komareki

73 rumijae based on the shape of the pronotum and body size. Because of the lowering of the status

74 of $P$. komareki to a subspecies of $P$. affinis, $P$. k. rumijae became synonymous of $P$. a. komareki,

75 which was confirmed by Chobanov and Heller (2010). On the other hand, Ingrisch \& Pavicevic

76 (2010) suggested regarding P. rumijae as a separate species, differing distinctly from P. affinis.

77 Morphological variability in these taxa was determined only based on minor differences in the

78 shape of the pronotum and body size (Chobanov \& Heller, 2010). Furthermore, song of $P$. $a$.

79 komareki and $P$. rumijae resembles that of $P$. pseudornatus with a long silent beginning. Song of

$80 P$. nonveilleri is short with a typical structure, whereas $P$. a. affinis has also short song and shows

81 morphological differences to $P$. nonveilleri (own unpublished data). Due to the discrepancy

82 between the authors, $P$. rumijae will also be treated separately in the present study. Poecilimon

83 pseudornatus, $P$. nonveilleri and the subspecies of $P$. affinis are morphologically similar,

84 although a recent molecular study based on the cytochrome c oxidase I gene has shown that the

85 above taxa do not form a monophyletic group (Kociński, 2020). The lack of clear boundaries

86 between them and the unsolved phylogenetic relationship suggest that $P$. pseudornatus, $P$.

87 nonveilleri and subspecies of $P$. affinis should be treated as the $P$. affinis complex.

88 The 'species complex' is an informal taxonomic term showing the uncertainty of

89 taxonomic identification (Sigovini et al., 2016) and it is commonly used in insects (e.g., Genier

90 \& Moretto, 2017; Manani et al., 2017; Elfekih et al., 2018; Selnekovič \& Kodada, 2019). It may

91 be defined as a group of very closely-related taxa with similar morphology and difficult to 
92 distinguish from one another. Taxa from a complex require a critical revision in order to clarify

93 the actual taxonomic position (Sigovini et al., 2016).

94 To determine the morphological variation of the Poecilimon ornatus group, especially

95 within the Poecilimon affinis complex, we used geometric morphometric methods based on the

96 shape variation of four structures: pronotum, male cercus, ovipositor, and tegmen (Fig. 2).

97 Geometric morphometrics is an approach that applies the landmark coordinates, which are the

98 correspondence points marked on a given morphostructure and are the same in all studied

99 specimens or species (Bookstein, 1991; Dryden \& Mardia, 1998). This method considers the

100 spatial relationships between landmark variables, therefore providing more powerful statistical

101 results. It is also possible to find and analyze shape variations in the species within and between

102 populations (Walker \& Bell, 2000). The geometric morphometric method has been proved to be

103 very useful for distinguishing species in insects (Nunes et al., 2012; Prado-Silva et al., 2016; da

104 Silva et al., 2018), especially in Orthoptera (Romero, Rosetti \& Remis, 2014; Barcebal et al.,

105 2015; Kaya, Boztepe \& Ciplak, 2015; Kaya et al., 2015; Mugleston et al., 2016; Bian \& Shi,

106 2018; Pan, Hong \& Jiang, 2018; Liu, Chen \& Liu, 2020). The aim of the present study is to

107 assess the morphological diversity of the species within the $P$. ornatus group, outline morpho-

108 units and discuss the importance of morphological traits for the systematics of the group. We test

109 the hypothesis of the existence of the P. affinis complex.

110

\section{Materials \& Methods}

\section{Specimen collection}

113 Bush-crickets were collected in the Balkan Peninsula (Bulgaria, Serbia, Montenegro, Albania,

114 North Macedonia, Greece) between 2017 and 2019 and stored in 96\% ethanol (Table 1). In 
115 Greece, field studies were approved by the Greek Ministry of the Environmental, Energy, and

116 Climate Change (No 154812/951).

117

118 Geometric morphometrics

119 In total, 196 specimens belonging to 16 taxa of the Poecilimon ornatus group were used for

120 geometric morphometric analyses. Four morphostructures (pronotum, male cercus, ovipositor,

121 and tegmen) were photographed using a stereomicroscope (Leica M165C) equipped with a

122 digital camera (Leica DMC5400) under strictly maintained magnification and resolution and

123 saved in jpg format. TPS files for each structure were created from the photographs with the

124 software tpsUtil v.1.26 following Rohlf (2004). To explore the patterns of morphological

125 variation, 8 landmarks (including 1 semilandmark) of pronotum, 13 (7 semilandmarks) of cercus,

12613 (1 semilandmark) of tegmen, and 9 (2 semilandmarks) of ovipositor (Fig. 2) were plotted

127 manually in tpsDIG2 v.2.17 (Rohlf, 2015). The list of landmarks and semilandmarks used in this

128 study is included in Table 2. After plotting the landmarks, the intersections marked in the TPS

129 files were aligned using a Procrustes superimposition. Partial warp scores were studied using

130 Canonical variate analysis (CVA) for each structure in MorphoJ v.1.06d (Klingenberg, 2011).

131 The first two Canonical Variables (CVs) with the greatest power to distinguish the groups were

132 plotted in the same software. The Mahalanobis distance was measured and statistically tested

133 using 10,000 permutation repeats.

134

135 Stridulatory measurements

136 The length of the stridulatory file and the number of stridulatory teeth were calculated for 154

137 specimens from the $P$. ornatus group (9 specimens of $P$. affinis, $24-$ P. affinis affinis, $1-P$. 
138 affinis dinaricus, 7 - P. affinis hajlensis, 5-P. affinis komareki, 12 - P. affinis serbicus, 8 - P.

139 hoelzeli, 3 - P. jablanicensis, $15-P$. nobilis, $10-P$. nonveilleri, $12-P$. obesus, $10-P$.

140 ornatus, $29-$ P. pseudornatus, 8 - P. soulion). Measurements were taken under

141 stereomicroscope with the aid of an ocular micrometer. For measurement of the stridulatory file

142 length, we used the distance from the first proximal (basal) to the last distal (apical) tooth. The

143 tegmen was placed upside down so that the stridulatory file could be viewed with its proximal

144 and distal ends being at the same level. This way, the distance between the ends was measured

145 along the imaginary line connecting those. The total number of stridulatory teeth and the number

146 of teeth within $2 \mathrm{~mm}$ at the middle of the stridulatory file were counted. Measurement data were

147 analyzed using Principal Component Analysis (PCA) in Past 4.03

148 (https://www.nhm.uio.no/english/research/infrastructure/past/).

\section{Phylogenetic analyses}

151 A fragment of the cytochrome $\mathrm{c}$ oxidase subunit I (COI) of mitochondrial DNA (mtDNA) was

152 used to determine the phylogenetic relationship between the taxa. We aimed to construct a

153 phylogenetic tree focusing on the species of the $P$. affinis complex. A total of 71 sequences of 14

154 Poecilimon taxa were obtained from GenBank (https://www.ncbi.nlm.nih.gov/genbank/). The

155 DNA sequences were aligned using CodonCode Aligner 9.0.2

156 (https://www.codoncode.com/aligner) with default parameters. The maximum likelihood (ML)

157 and Bayesian inference (BI) analyses were used to infer the phylogenetic relationships. The best-

158 fit model of nucleotide substitution was determined with jModelTest2 (Guindon \& Gascuel,

159 2003; Darriba et al., 2013). ML was performed in IQ-TREE (Nguyen et al., 2015), whereas BI

160 in MrBayes 3.2. (Ronquist et al., 2012). For bootstrap analyses, 1,000 pseudoreplicates were 
161 generated. BI was carried out with 10,000,000 generations, with a sampling of trees every 100

162 generations. Likelihood values were observed with Tracer v.1.7 (Rambaut et al., 2018). The tree

163 was visualized in FigTree 1.4.4 (Rambaut, 2018).

164

165 Results

166 Morphology

167 As a result, 54 images of ovipositor, 130 of tegmen, 142 of pronotum, and 141 of male cercus

168 were used in the analyses. In some specimens, tegmen and male cercus were damaged and not

169 used for this study. The landmarks were chosen based on the shape and structure of the

170 ovipositor (7 landmarks, 2 semilandmarks) (Fig. 2A), male cercus (6 landmarks, 7

171 semilandmarks) (Fig. 2B), pronotum (7 landmarks, 1 semilandmark) (Fig. 2C), and tegmen (12

172 landmarks, 1 semilandmark) (Fig. 2D).

$173 \mathrm{CV}$ analysis of the tegmen (Fig. 3) revealed significant variation within the P. ornatus group

174 and P. affinis complex. At the species group level, the first two CV analyses together accounted

175 for $77.72 \%$ of the total variation $(\mathrm{CV} 1=55.64 \%, \mathrm{CV} 2=22.08 \%)$. A combination of the results of

176 the CV1 and CV2 analyses of the tegmen separated the species $P$. hoelzeli, P. obesus, $P$.

177 jablanicensis and P. nobilis from the other species of the Poecilimon ornatus group and revealed

178 an overlap between P. pseudornatus, P. poecilus, P. nonveilleri, and P. affinis (Fig. 3A). The

179 Mahalanobis distance obtained through pairwise comparisons among the group revealed highly

180 significant differences $(10,000$ permutation rounds; $\mathrm{P}<0.0001)$, ranging from 2.50 ( $P$. affinis and

181 P. pseudornatus) to 19.66 (P. poecilus and P. obesus). The Procrustes distances also showed

182 significant differences between groups $(10,000$ permutation rounds; $\mathrm{P}<0.0001)$ ranging from

1830.03 (P. poecilus and P. pseudornatus) to 0.28 (P. nobilis and P. obesus) (Table S1). 
184 At the species complex level, the first two CVs together accounted for $47.9 \%$ of the total

185 variation of the tegmen $(\mathrm{CV} 1=28.5 \%$ and $\mathrm{CV} 2=19.4 \%) . \mathrm{CV} 1$ and $\mathrm{CV} 2$ analyses of the

186 Poecilimon affinis complex did not indicate clear clusters representing each of the existing

187 species/subspecies. However, the specimens of $P$. a. affinis show differentiation in terms of their

188 occurrence (Bratiya, Kirilova Polyana, Yavorow-Pirin, Osogovo, Rila) in contrast to $P$.

189 pseudornatus, where specimens from different localities (Kamena Gora, Durmitor, Treschnievik,

190 Vusanje) are grouped together (Fig. 3B). The Mahalanobis distances between taxa for tegmen

191 are 2.77 for P. poecilus and P. pseudornatus, and 8.13 for P. a. komareki and P. a. dinaricus

192 (10,000 permutation rounds; $\mathrm{P}<0.0001)$. The Procrustes distances also showed significant

193 differences $(10,000$ permutation rounds; $\mathrm{P}<0.001)$, ranging from 0.03 (P. a. serbicus and $P$.

194 pseudornatus) to 0.12 (P. rumijae and P. a. dinaricus) (Table S2).

195 For the ovipositor, at the species group level, the first two CVs together accounted for

$19678.43 \%$ of the total variation $(\mathrm{CV} 1=54.78 \%, \mathrm{CV} 2=23.65 \%)($ Fig. $4 \mathrm{~A})$. The scatter plot from CV1

197 and CV2 shows that species from the Poecilimon affinis complex cannot be clearly separated

198 from other species of the Poecilimon ornatus group (Fig. 4A). The Mahalanobis distances

199 obtained by pairwise comparisons among group revealed highly significant differences $(10,000$

200 permutation rounds, $\mathrm{P}<0.0001)$, ranging from 2.78 ( $P$. poecilus and $P$. hoelzeli) to $15.72(P$.

201 gracilis and $P$. nobilis). The Procrustes distances also showed significant differences between

202 groups $(10,000$ permutation rounds, $\mathrm{P}<0.0001)$ ranging from 0.04 ( $P$. affinis and $P$. hoelzeli) to

2030.19 (P. pseudornatus and P. gracilis) (Table S3).

204 At the species complex level, the first two CVs together accounted for $83.92 \%$ of the total

205 variation of the ovipositor $(\mathrm{CV} 1=70.26 \%$ and $\mathrm{CV} 2=13.66 \%)(\mathrm{Fig} .4 \mathrm{~B})$. The centroid size (the

206 square root of the sum of the squared distances of all landmarks from their centroid) of CV1 and 
207 CV2 shows that species from the Poecilimon affinis complex can be clearly separated from each

208 other (Fig. 4B). The Mahalanobis distances obtained through pairwise comparisons of the

209 complex revealed highly significant differences $(10,000$ permutation rounds; $\mathrm{P}<0.0001)$, ranging

210 from 2.69 (P. rumijae and P. a. affinis) to 14.50 (P. pseudornatus and P. a. hajlensis). The

211 Procrustes distances also showed highly significant differences $(10,000$ permutation rounds;

$212 \mathrm{P}<0,005$ ), ranging from 0.03 (P. a. serbicus and P. a. affinis) to 0.15 (P. a. komareki and P. a.

213 dinaricus) (Table S4).

214 CV analysis of the male cercus (Fig. 5) also revealed significant variation within the $P$.

215 ornatus group and the $P$. affinis complex. At the group level, the first two CVs together

216 accounted for $69.82 \%$ of the total variation $(\mathrm{CV} 1=40.59 \%, \mathrm{CV} 2=29.23 \%)$. The scatter plot from

217 CV1 and CV2 shows that species from the Poecilimon affinis complex can be clearly separated

218 from other species of the Poecilimon ornatus group (Fig. 5A). The Mahalanobis distances

219 obtained through pairwise comparisons among group revealed highly significant differences

220 (10,000 permutation rounds; $\mathrm{P}<0.0001)$, ranging from 2.71 (P. pseudornatus and $P$. affinis) to

22112.25 (P. hoelzeli and P. jablanicensis). The Procrustes distances also showed significant

222 differences between groups $(10,000$ permutation rounds; $\mathrm{P}<0.0001)$, ranging from $0.03(P$.

223 affinis and P. pseudornatus) to 0.17 (P. pseudornatus and P. nobilis) (Table S5).

224 For the male cercus, at the complex level, the first two CVs together accounted for $54.33 \%$ of 225 the total variation $(\mathrm{CV} 1=30.38 \%$ and $\mathrm{CV} 2=23.95 \%)$. The centroid size of $\mathrm{CV} 1$ and $\mathrm{CV} 2$ shows

226 that only $P$. a. affinis, $P$. rumijae, $P$. a. komareki, and $P$. nonveilleri can be clearly separated

227 from other members of the $P$. affinis complex (Fig. 5B). The Mahalanobis distances obtained

228 through pairwise comparisons of the complex revealed significant differences $(10,000$

229 permutation rounds; $\mathrm{P}<0.0001$ ), ranging from 2.87 (P. pseudornatus and P. a. hajlensis) to 8.65 
230 (P. a. dinaricus and P. a. komareki). The Procrustes distances also showed significant

231 differences $(10,000$ permutation rounds; $\mathrm{P}<0.0001)$, ranging from 0.03 ( $P$. a. affinis and $P$.

232 poecilus) to 0.10 (P. a. komareki and P. nonveilleri) (Table S6).

233 For the pronotum, at the group level, the first two CVs together accounted for $75.84 \%$ of the

234 total variation $(\mathrm{CV} 1=57.24 \%, \mathrm{CV} 2=18,60 \%)$ (Fig. 6). The scatter plot from CV1 and CV2

235 shows that species from the Poecilimon affinis complex cannot be clearly separated from other

236 species of the Poecilimon ornatus group (Fig. 6A). The Mahalanobis distances obtained through

237 pairwise comparisons among group revealed significant differences (10,000 permutation rounds;

$238 \mathrm{P}<0.0001$ ), ranging from 2.20 (P. poecilus and P. affinis) to 12.81 (P. gracilis and P. obesus).

239 The Procrustes distances also showed significant differences between groups $(10,000$

240 permutation rounds; $\mathrm{P}<0.0001$ ), ranging from 0.03 (P. poecilus and $P$. affinis) to 0.16 ( $P$. gracilis

241 and P. jablanicensis) (Table S7).

242 At the complex level, the first two CVs together accounted for $72.01 \%$ of the total

243 variation of the pronotum $(\mathrm{CV} 1=46.56 \%$ and $\mathrm{CV} 2=25.45 \%)$. The centroid size of $\mathrm{CV} 1$ and $\mathrm{CV} 2$

244 shows that only P. rumijae can be clearly separated from other species from the $P$. affinis

245 complex (Fig. 6B). The Mahalanobis distances obtained through pairwise comparisons of the

246 complex revealed significant differences (10,000 permutation rounds; $\mathrm{P}<0.0001)$, ranging from

2472.73 (P. a. hajlensis and P. a. affinis) to 5.68 (P. rumijae and P. nonveilleri). The Procrustes

248 distances also showed highly significant differences $(10,000$ permutation rounds; $\mathrm{P}<0.0001)$,

249 ranging from 0.04 (P. poecilus and P. a. affinis) to 0.14 (P. rumijae and P. nonveilleri) (Table

250 S8).

251

252 Stridulatory measurements 
253 Poecilimon soulion and $P$. jablanicensis have the shortest stridulatory file of all studied species

254 (2.74-3.17 and $2.96-3.04$, respectively). In contrast, $P$. affinis komareki has the longest

255 stridulatory file $(5.34-5.88)$ and the greatest number of teeth on its structure $(158-195)$.

256 Poecilimon obesus has the lowest number of teeth, which proves that the length of the

257 stridulatory file does not correlate with the number of teeth (Table 3). Principal Component

258 Analysis of the stridulatory file and the number of teeth shows that $P$. nonveilleri, $P$. ornatus, $P$.

259 hoelzeli, P. pseudornatus, P. a. serbicus, P. a. hajlensis, and P. a. affinis overlap. Moreover, we

260 can conclude that $P$. a. affinis is the most diverse taxon within the P. ornatus group, while $P$. a.

261 komareki is the most distinct taxon of the studied group (Fig. 7).

262

263 Phylogenetic analyses

264 The final alignment consists of $607 \mathrm{bp}$, of which 450 were conservative, 157 variable and 83

265 parsimony-informative sites. $\mathrm{HKY}+\mathrm{G}$ was selected as the best-fit evolution model for site

266 substitution. The topologies obtained from BI and ML analyses were similar. Bootstrap values

267 (ML) ( $>50 \%)$ and BI posterior probabilities $(>0.5)$ are shown on the nodes of the tree presented

268 on Fig. 8. To root the tree, Poecilimon cervus Karabag, 1950, belonging to the Poecilimon

269 bosphoricus Brunner von Wattenwyl, 1878 species group, was chosen. The BI and ML trees

270 based on the COI data show that the $P$. affinis complex forms a paraphyletic group. The most

271 diverse taxon in the complex is $P$. a. affinis, occupying different nodes on the phylogenetic tree

272 due to its place of occurrence. Poecilimon a. affinis from Kirilova Polyana (Bulgaria, Rila Mtns)

273 occupies a basal position in the tree and seems to be a sister taxon to the remaining taxa of the

274 complex. Two species of the $P$. ornatus group, preliminary left outside the $P$. affinis complex, $P$.

275 ornatus and P. hoelzeli, were placed within the same clade (Fig. 8). 


\section{Discussion}

\section{Morphology}

279 This work aimed to determine the morphological characteristics that separate bush-crickets

280 belonging to the $P$. affinis complex from other species of the $P$. ornatus group through the

281 geometric morphometrics approach. The morphology of the tegmen, ovipositor, male cercus and

282 pronotum were used successfully in morphological studies of Poecilimon (Heller, 2004;

283 Chobanov \& Heller, 2010; Kaya et al., 2012; Kaya, Boztepe \& Ciplak, 2015; Kaya et al., 2018).

284 The present work showed that the studied morphostructures can partly be used to separate taxa of 285 the species rank in the Poecilimon ornatus group. Chobanov \& Heller (2010) noticed that the 286 pronotal shape and the size of the area of the tegmen covered by the pronotum vary between

287 specimens from the same locality. Our results support the poor taxonomic utility of the shape of 288 pronotum in this group for distinguishing the species belonging to the $P$. affinis complex from 289 other species in the group (Fig. 6A). However, based on the shape of the tegmen, P. affinis and 290 its subspecies group with $P$. nonveilleri, . pseudornatus in the same place, which clearly

291 separates them from other species (Fig. 3A). This may confirm our assumption for the

292 designation of the $P$. affinis complex including other species from the Poecilimon ornatus group.

$293 \mathrm{CV}$ analysis of centroid sizes of the pronotum (Fig. 6B) shows that P. rumijae is the most

294 distinct taxon among the P. affinis complex, and does not overlap with P. a. komareki.

295 Poecilimon rumijae may likely be treated as a separate species of the $P$. ornatus group, differing

296 distinctly from subspecies of $P$. affinis (Ingrisch \& Pavicevic, 2010), but further studies are

297 required to confirm its taxonomic position. This assumption is also confirmed by the analysis of

298 the ovipositor, where $P$. a. komareki is more similar to $P$. a. dinaricus and P. pseudornatus, 
299 whereas P. rumijae is more similar to $P$. a. affinis (Fig. 4B). On the other hand, the results based

300 on the male cercus (Fig. 5B) show that P. a. komareki and P. rumijae overlap, which proves high

301 similarities within this morphostructure and may confirm the accuracy of lowering P. rumijae to

302 the rank synonymous with P. a. komareki (Chobanov \& Heller, 2010; Cigliano et al., 2021).

303 Ingrisch \& Pavicevic (2010) considered P. rumijae to be similar to P. nonveilleri and P. affinis.

304 Our results confirm a close relationship between $P$. rumijae and $P$. affinis, but not between $P$.

305 rumijae and $P$. nonveilleri, which, according to all morphostructures, are the most distant from

306 each other (Fig. 3A, 4A, 5A, 6A).

307 The most distinct species in our sample is P. nobilis based on the analysis of the tegmen

308 (Fig. 3A) and male cercus (Fig. 5A), P. gracilis based on the ovipositor (Fig. 4A), and P. obesus

309 based on the pronotum (Fig. 6A), which suggest not to include these species in the $P$. affinis

310 complex. On the other hand, $P$. affinis is the most diffuse taxon in the group (Fig. 3A, 4A, 5A,

311 6A). The results suggest that the difference between specimens of $P$. a. affinis is related to the

312 locality in which they occur (Fig. 3B), and is generally connected with altitude (Chobanov \&

313 Heller, 2010). Specimens of P. a. affinis from Pirin are distant from individuals from Bratiya,

314 Kirilowa Polyana, Osogovo, Rila and are more closely related to P. poecilus, $P$. a. hajlensis and

315 P. a. komareki (Fig. 3B). On the other hand, the position of the centroid size of P. pseudornatus

316 from different localities (Durmitor, Kamena Gora, Treshnievik, Vusanje) overlaps, which proves

317 a lower morphological variability in terms of location than in the case of P. a. affinis (Fig. 3B).

318 At the group level based on the male cercus (Fig. 5A), species from the P. affinis complex ( $P$.

319 affinis with its subspecies, $P$. nonveilleri and P. pseudornatus) overlap. Thus, this is the second

320 morphostructure to confirm the existence of this complex. Additionally, Chobanov \& Heller

321 (2010) suggested that the male cercus may be a better feature for separating species in this group. 
322 The results of the CV analysis of centroid size of the ovipositor (Fig. 4A) show the similarity

323 between $P$. affinis, $P$. hoelzeli, P. pseudornatus, P. poecilus, and P. nonveilleri, which may

324 indicate the extension of the P. affinis complex with P. hoelzeli (Fig. 4A). Poecilimon poecilus,

325 which we suggested to treat separately in this work, seems to fell within the variation of $P$. a.

326 affinis. It is confirmed by all the morphostructures studied, where $P$. poecilus overlaps with other

327 subspecies: P. a. affinis, P. a. hajlensis, P. a. komareki (Fig. 3A, 4A, 5A, 6A). However, to

328 establish the taxonomic status of $P$. poecilus, additional research is needed.

330 Stridulatory structures measurements

331 The stridulatory file and the number of teeth can be a good morphological feature for

332 distinguishing taxa in the P. ornatus group (Heller, 1984; Willemse, 1985; Heller, 1988;

333 Chobanov \& Heller, 2010). Heller (1988) reports that P. ornatus has fewer teeth than P. affinis,

334 about 158-212, with some exceptions of large specimens having up to 220 teeth, as confirmed by

335 our results (Table 3). The length of stridulatory file is the same in both species and averaged

336 4.08. Thus, this morphostructure and the number of teeth are not a good feature for

337 distinguishing $P$. affinis from $P$. ornatus. Heller (1984) observed about 220-230 teeth in $P$.

338 affinis species, while Chobanov \& Heller (2010) observed 180-240. They suggest that the

339 number is generally more variable in southeastern populations (SW Bulgaria). The lowest

340 number of teeth is found in small specimens from high altitudes. Principal Component Analysis

341 (PCA) shows a similarity between three subspecies (P. a. affinis, P. a. serbicus and P. a.

342 hajlensis) (Fig. 7). On the other hand, P. a. komareki does not overlap with other subspecies,

343 which may mean that it is the most distinct taxon from all studied taxa of the P. ornatus group.

344 Poecilimon hoelzeli and P. pseudornatus have a similar number of teeth and length of the 
345 stridulatory file. Poecilimon ornatus, $P$. nonveilleri, P. a. affinis, $P$. a. hajlensis, P. a. serbicus,

$346 \quad P$. pseudornatus and $P$. hoelzeli overlap, which can suggest that $P$. hoelzeli and $P$. ornatus should

347 be included in the designated $P$. affinis complex.

348

349 Phylogenetic data

350 The first genetic studies using ribosomal internal transcribed spacers (ITS1 and 2)

351 involving some of the group's species were conducted by Ullich et al. (2010). However, they

352 did not provide conclusive information on the relationship between species in this group.

353 Kocinski (2020) performed a genetic analysis based on the cytochrome c oxidase I gene (COI) of

354 the P. ornatus group, and confirmed the monophyly of this group. Our results, focusing on

355 species from the P. affinis complex, show that it forms a paraphyletic group (Fig. 8). Two

356 additional species, $P$. hoelzeli and $P$. ornatus, are distributed with the other taxa of the complex,

357 thus they probably should be included in the P. affinis complex determined previously. This

358 assumption is similar to the results of the CVA of the ovipositor, where taxa from the complex

359 overlap with P. hoelzeli (Fig. 4A). Moreover, based on the phylogenetic tree (Fig. 8), P. a. affinis

360 is the most diverse species in the complex, occupying different nodes, which is supported by the

361 CVA results of the tegmen (Fig. 3B). The variability is related to the location (Bratiya, Kirilova

362 Polyana, Rila, Yavorow) of the populations of $P$. a. affinis, and is connected with the altitude of

363 occurrence (Chobanov \& Heller, 2010). Poecilimon a. komareki and P. rumijae form different

364 nodes, which may suggest treating them as separate taxa of the $P$. ornatus group. This opinion is

365 confirmed by the CVA results of pronotum and ovipositor (Fig. 4B, 6B). The specimens from $P$.

366 poecilus also form different nodes compared to $P$. a. affinis, thus, it may be treated as a 
367 subspecies of $P$. affinis, which is supported by the CVA of the tegmen, male cercus, ovipositor,

368 and pronotum (Fig. 3B, 4B, 5B, 6B).

369 Conclusions

370 The geometric morphometric method has proven to be useful in studying the morphological

371 diversity of bush-crickets. Combined with the analysis of the stridulatory file and molecular

372 phylogeny, it provides better insight into the relationship between species from the Poecilimon

373 ornatus group, and in particular, the taxa of the Poecilimon affinis complex. Morphological

374 analysis of selected morphostructures and molecular data showed the paraphyly of the P. affinis

375 complex unless $P$. ornatus and $P$. hoelzeli are included. Additionally, the taxonomic status of the

376 P. rumijae and $P$. poecilus species remains unclear. Our results show some discordances with

377 previous studies and point to the need for a most thorough interdisciplinary phenetic and genetic

378 study in order to solve the systematics of this particular group of bush-crickets.

379

380 Acknowledgements

381 We thank the Biology Students' Research Society (BSRS; Skopje, Republic of North

382 Macedonia) and its 2017 chair, Marija Trencheva, for the accommodation and logistic support,

383 and Slobodan Ivković for the help in the field, during our collecting trips in Macedonia.

384

385

\section{References}

386

387

388

389

390

391

392
1. Barcebal GM, Coronel KHI, Torres MAJ, Demayo CG. 2015. Variability in the shape of the mandibles of grasshopper (Orthoptera: Acrididae) from selected places in Mindanao, Philippines. Advances in Environmental Biology 9(19 S4): 123-127.

2. Bian X, Shi F. 2018. New taxa of the genus Phlugiolopsis (Orthoptera: Tettigoniidae: Meconematinae) from Yunnan, China, with comments on the importance to taxonomy of the left tegmen. Zootaxa 4532(3): 341-366. 
393

394

395

396

397

398

399

400

401

402

403

404

405

406

407

408

409

410

411

412

413

414

415

416

417

418

419

420

421

422

423

424

425

426

427

428

429

430

431

432

433

434

435

436

437

3. Bookstein FL. 1991. Morphometric Tools for Landmark Data: Geometry and Biology. Cambridge University Press 435.

4. Chobanov DP, Heller KG. 2010. Revision of the Poecilimon ornatus group (Orthoptera: Phaneropteridae) with particular reference to the taxa in Bulgaria and Macedonia. European Journal of Entomology 107(4): 647-672.

5. Cigliano MM, Braun H, Eades DC, Otte D. 2021. Orthoptera Species File. Version 5.0/5.0. Available at http://Orthoptera.SpeciesFile.org (accessed 01 July 2021).

6. da Silva ACS, Nunes LA, de Lima Batista W, Lhano MG. 2018. Morphometric variation among males of Orphulella punctata (De Geer, 1773) (Acrididae: Gomphocerinae) from different biomes in Brazil. Journal of Orthoptera Research 27(2): 163-171.

7. Darriba D, Taboada GL, Doallo R, Posada D. 2013. jModelTest 2: more models, new heuristics and parallel computing. Nature Methods 9: 772 DOI: 10.1038/nmeth.2109.

8. Dryden IL, Mardia KV. 1998. Statistical Shape Analysis. John Wiley and Sons, Chichester, England 347.

9. Elfekih S, Etter P, Tay WT, Fumagalli M, Gordon K, Johnson E, De Barro P. 2018. Genome-wide analyses of the Bemisia tabaci species complex reveal contrasting patterns of admixture and complex demographic histories. PLoS One 13(1): e0190555.

10. Genier F, Moretto P. 2017. Digitonthophagus Balthasar, 1959: taxonomy, systematics, and morphological phylogeny of the genus revealing an African species complex (Coleoptera: Scarabaeidae: Scarabaeinae). Zootaxa 4248(1): 1-110.

11. Guindon S, Gascuel O. 2003. A simple, fast and accurate algorithm to estimate large phylogenies by maximum likelihood. Systematic Biology 52: 696-704 DOI: $10.1080 / 10635150390235520$.

12. Heller KG. 1984. Zur Bioakustik und Phylogenie der Gattung Poecilimon (Orthoptera, Tettigoniidae, Phaneropterinae). Zoologische Jahrbücher / Abteilung für Systematik 111: 69-117.

13. Heller KG. 1988. Bioakustik der europäischen Laubheuschrecken. Josef Margraf, Weikersheim 358.

14. Heller KG. 1990. Evolution of song pattern in east Mediterranean Phaneropterinae: Constraints by the communication system. In: Bailey WJ, Rentz DCF, ed. In The Tettigoniidae: biology, systematics and evolution. Berlin: Springer, 130-151.

15. Heller KG. 2004. Poecilimon martinae sp. $\mathrm{n}$ and P. inflatus Brunner von Wattenwyl, 1891 (Orthoptera, Tettigonioidea, Phaneropteridae), two bush-cricket species endemic to southwest Anatolia: morphology, bioacoustics and systematics. Articulata 19(1): 1-17.

16. Ingrisch S, Pavicevic D. 2010. Seven new Tettigoniidae (Orthoptera) and a new Blattellidae (Blattodea) from the Durmitor area of Montenegro with notes on previously known taxa. Zootaxa 2565: 1-41.

17. Karaman MS. 1972. Nouvelle sou-espèce de sauterelle Poecilimon komareki rumijae n.sp. (Orthopt. Phaneropterinae). Bulletin de la Societe entomologique de Mulhouse 1012.

18. Karaman MS. 1974. Beitrag zur Kenntnis der Art Poecilimon affinis (Friv.) (Orthoptera, Phaneropteridae). Reichenbachia 15: 23-31.

19. Kaya S, Boztepe Z, Çiplak B. 2015. Phylogeography of the Poecilimon luschani species group (Orthoptera, Tettigoniidae): a radiation strictly correlated with climatic transitions in the Pleistocene. Zoological Journal of the Linnean Society 173(1): 1-21.

PeerJ reviewing PDF | (2021:09:65770:1:1:NEW 15 Nov 2021) 
438

439

440

441

442

443

444

445

446

447

448

449

450

451

452

453

454

455

456

457

458

459

460

461

462

463

464

465

466

467

468

469

470

471

472

473

474

475

476

477

478

479

480

481
20. Kaya S, Chobanov D, Heller KG, Yahyaoğlu ÖZGÜL, Uluar O, Çıplak B. 2018. Review of Poecilimon species with inflated pronotum: description of four new taxa within an acoustically diverse group. Zootaxa 4462(4): 451-482.

21. Kaya S, Ciplak B, Chobanov D, Heller KG. 2012. Poecilimon bosphoricus group (Orthoptera, Phaneropterinae): iteration of morpho-taxonomy by song characteristics. Zootaxa 3225(1): 1-71.

22. Kaya S, Chobanov DP, Skejo J, Heller KG, Ciplak B. 2015. The Balkan Psorodonotus (Orthoptera: Tettigoniidae): Testing the existing taxa confirmed presence of three distinct species. European Journal of Entomology 112(3): 525.

23. Klingenberg CP. 2011. MorphoJ: an integrated software package for geometric morphometrics. Molecular ecology resources 11(2): 353-357.

24. Kociński M. 2020. The Relationships within the Poecilimon ornatus group (Orthoptera: Phaneropterinae) based on the cytochrome C oxidase I gene. Folia Biologica 68(1): 7-13.

25. Liu F, Chen L, Liu C. 2020. Taxonomic Studies of the genus Decticus Serville, 1831 from China (Orthoptera: Tettigoniidae: Tettigoniinae), based on Morphology and Songs. Zootaxa 4860(4): zootaxa-4860.

26. Manani DM, Ateka EM, Nyanjom SR, Boykin LM. 2017. Phylogenetic relationships among whiteflies in the Bemisia tabaci (Gennadius) species complex from major cassava growing areas in Kenya. Insects 8(1): 25.

27. Mugleston J, Naegle M, Song H, Bybee SM, Ingley S, Suvorov A, Whiting MF. 2016. Reinventing the leaf: multiple origins of leaf-like wings in katydids (Orthoptera: Tettigoniidae). Invertebrate Systematics 30(4): 335-352.

28. Nguyen LT, Schmidt HA, Von Haeseler A, Minh BQ. 2015. IQ-TREE: a fast and effective stochastic algorithm for estimating maximum-likelihood phylogenies. Molecular biology and evolution, 32(1): 268-274.

29. Nunes EN, Anselmo MDGV, Alves FAL, Holanda AE, Rosa JH, Alves CAB, de Lucena RFP, Souto JS. 2012. Análise da taxa de decomposição da serrapilheira na Reserva Ecológica Mata do Pau-Ferro, Areia-PB. Revista Gaia Scientia 6(1): 1-6.

30. Pan ZX, Hong F, Jiang GF. 2018. Morphometrics reveal correlation between morphology and bioclimatic factors and population mixture in Tetrix japonica (Orthoptera: Tetrigidae). Acta Zoologica 99(2): 199-210.

31. Prado-Silva A, Nunes LA, de Oliveira Alves RM, Carneiro PLS, Waldschmidt AM. 2016. Variation of fore wing shape in Melipona mandacaia Smith, 1863 (Hymenoptera, Meliponini) along its geographic range. Journal of Hymenoptera Research 48: 85.

32. Rambaut A, Drummond AJ, Xie D, Baele G, Suchard MA. 2018. Posterior summarisation in Bayesian phylogenetics using Tracer 1.7. Systematic Biology 67(5): 901-904.

33. Rambaut A. 2018. FigTree v1.4.4. https://github.com/rambaut/figtree.

34. Ramme W. 1933. Revision der Phaneropterinen-Gattung Poecilimon Fisch. (Orth. Tettigon). Mitteilungen aus dem Zoologischen Museum in Berlin 19: 497-575.

35. Rohlf FJ. 2004. tpsUtil v. 1.26. Department of Ecology and Evolution, State University of New York at Stony Brook.

36. Rohlf FJ. 2015. The tps series of software. Hystrix, the Italian Journal of Mammology 26: 9-12 DOI: 10.4404/hys-trix-26.1-11264. 
482

483

484

485

486

487

488

489

490

491

492

493

494

495

496

497

498

499

500

501

502

503

504

505
37. Romero ML, Rosetti N, Remis MI. 2014. Morphometric variation affecting sexual size dimorphism in Neopedies brunneri (Orthoptera: Acrididae). Annals of the Entomological Society of America 107(1): 257-263.

38. Ronquist F, Teslenko M, Van Der Mark P, Ayres DL, Darling A, Höhna S, Larget B, Liu L, Suchard MA, Huelsenbeck JP. 2012. MrBayes 3.2: Efficient Bayesian Phylogenetic Inference and Model Choice Across a Large Model Space. Systematic Biology 61(3): 539-542 DOI: 10.1093/sysbio/sys029.

39. Selnekovič D, Kodada J. 2019. Taxonomic revision of Mordellistenahirtipes species complex with new distribution records (Insecta, Coleoptera, Mordellidae). ZooKeys 854: 89.

40. Sigovini M, Keppel E, Tagliapietra D. 2016. Open Nomenclature in the biodiversity era. Methods in Ecology and Evolution 7(10): 1217-1225.

41. Ullrich B, Reinhold K, Niehuis O, Misof B. 2010. Secondary structure and phylogenetic analysis of the internal transcribed spacers 1 and 2 of bush crickets (Orthoptera:Tettigoniidae: Barbitistini). Journal of Zoological Systematics and Evolutionary Research 48: 219-228 DOI: 10.1111/j.1439-0469.2009.00553.x.

42. Walker JA, Bell MA. 2000. Net evolutionary trajectories of body shape evolution within a microgeographic radiation of threespine sticklebacks (Gasterosteus aculeatus). Journal of Zoology 252(3): 293-302.

43. Willemse F, Heller KG. 1992. Notes on systematics of Greek species of Poecilimon Fischer, 1853 (Orthoptera: Phaneropterinae). Tijdschrift voor Entomologie 135: 299-315. 44. Willemse F. 1985. Supplementary Notes on the Orthoptera of Greece Ia. Fauna Graeciae 1a. Hellenic Zoological Society 47. 


\section{Figure 1}

Representatives of the studied taxa from the Poecilimon ornatus group.

(A) P. affinis hajlensis. (B) P. affinis affinis. (C) P. hoelzeli. (D) P. rumijae. (E) P. nonveilleri. (F) P. poecilus. (G) P. pseudornatus. (H) P. ornatus. Photos D. Chobanov.

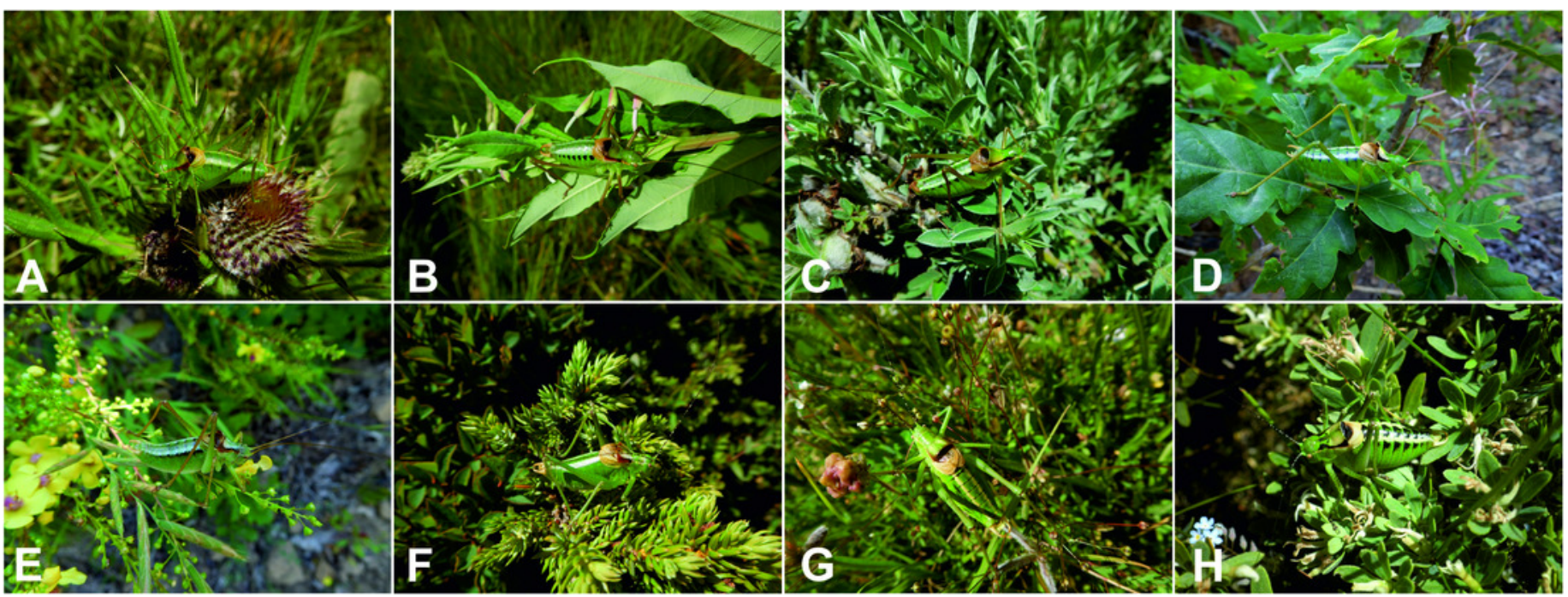




\section{Figure 2}

Position of the landmarks (red dots) on Poecilimon species used for geometric morphometrics.

(A) ovipositor. (B) male cercus. (C) pronotum. (D) tegmen.
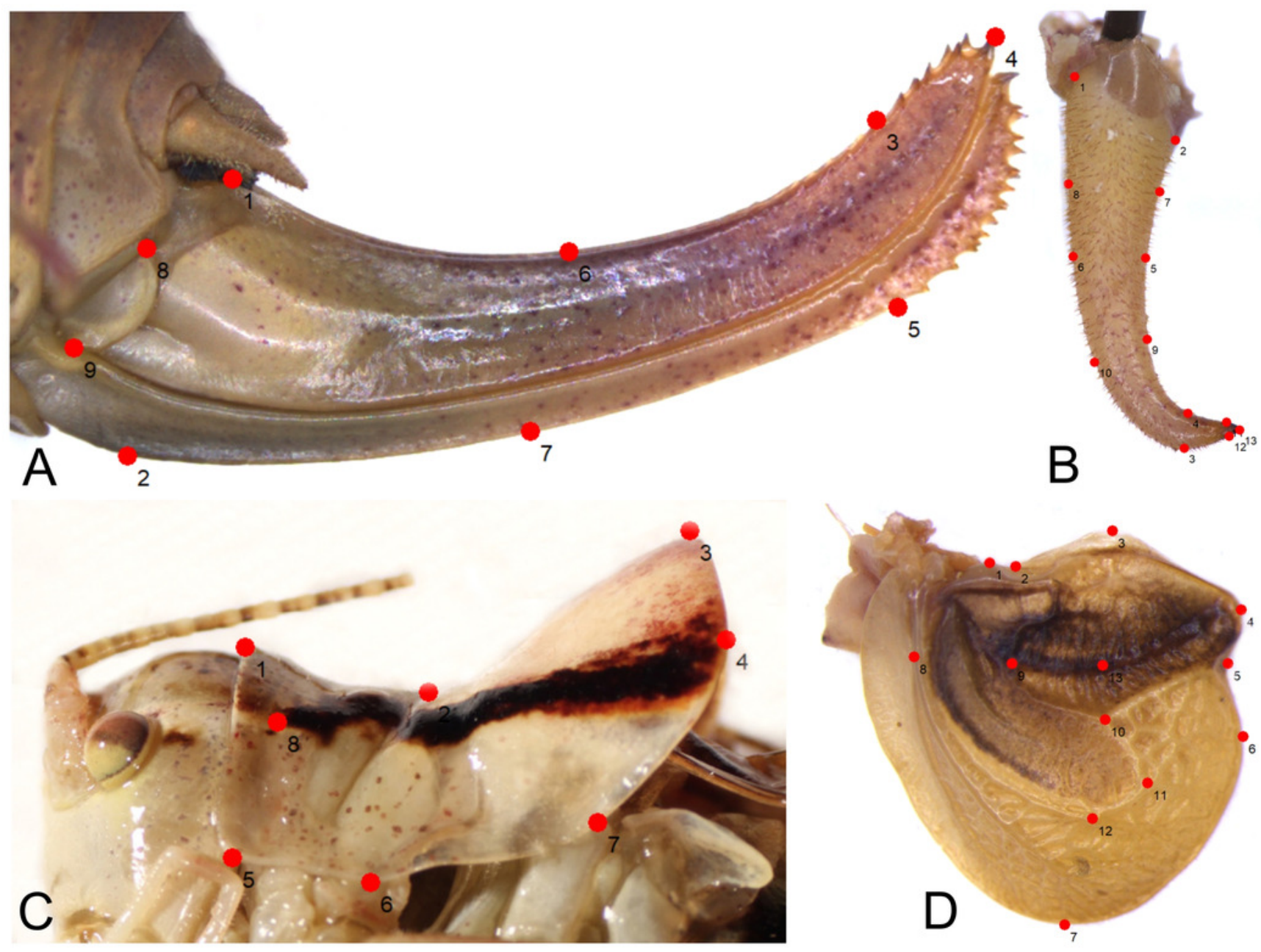
Figure 3

Scatter plot of the two first canonical variate axes (CV1 and CV2) analysis of centroid sizes of tegmen:P. ornatus group (A) and $P$. affinis complex (B).

The different colors of the species $P$. pseudornatus and $P$. a. affinis indicate different locations from which the specimens were collected. The localities are indicated below taxa name (SR - Serbia, MN - Montenegro, BG - Bulgaria).
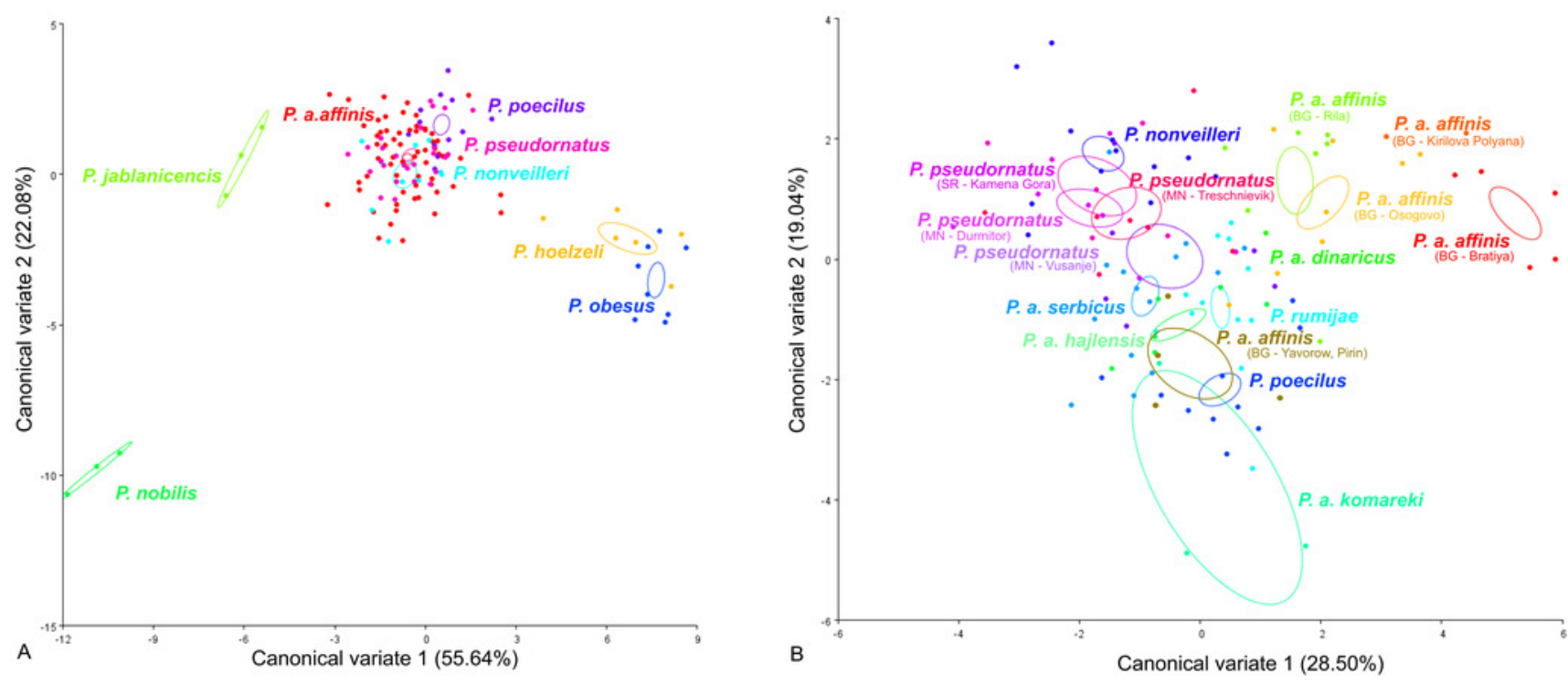
Figure 4

Scatter plot of the two first canonical variate axes (CV1 and CV2) analysis of centroid sizes of ovipositor: $P$. ornatus group (A) and $P$. affinis complex (B).

The different colors indicate different species/subspecies of studied bush-crickets.
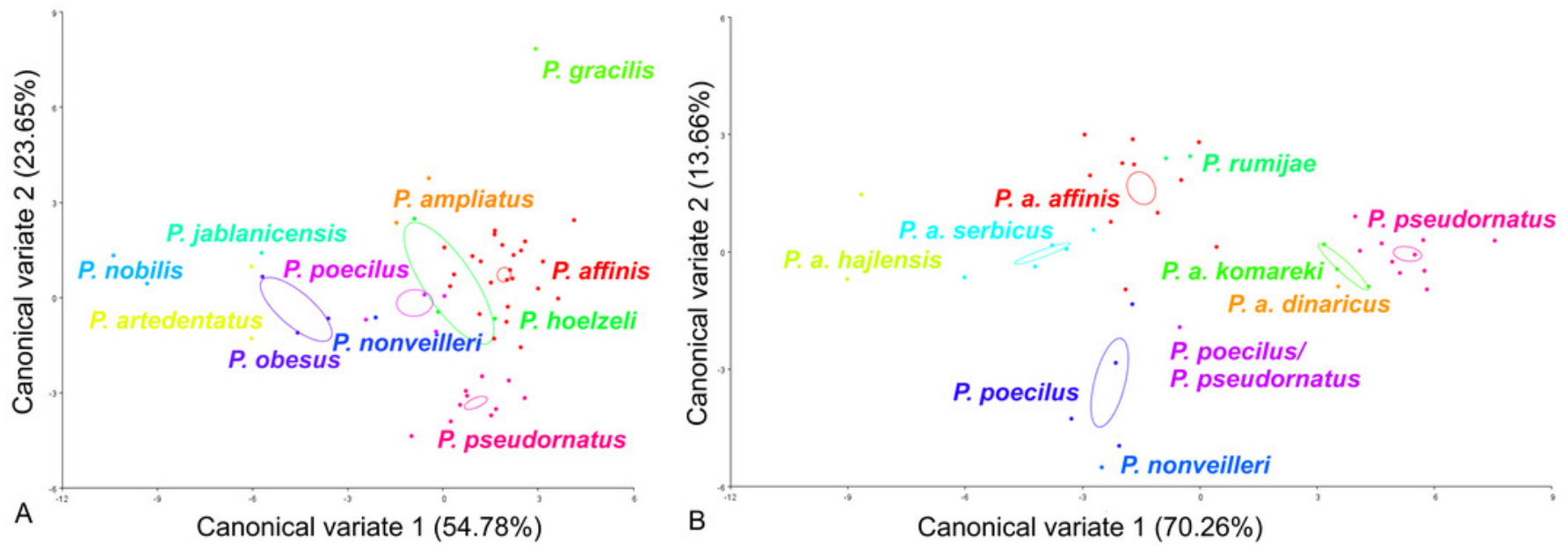
Figure 5

Scatter plot of the two first canonical variate axes (CV1 and CV2) analysis of centroid sizes of male cercus: $P$. ornatus group (A) and $P$. affinis complex (B).

The different colors indicate different species/subspecies of the studied bush-crickets.
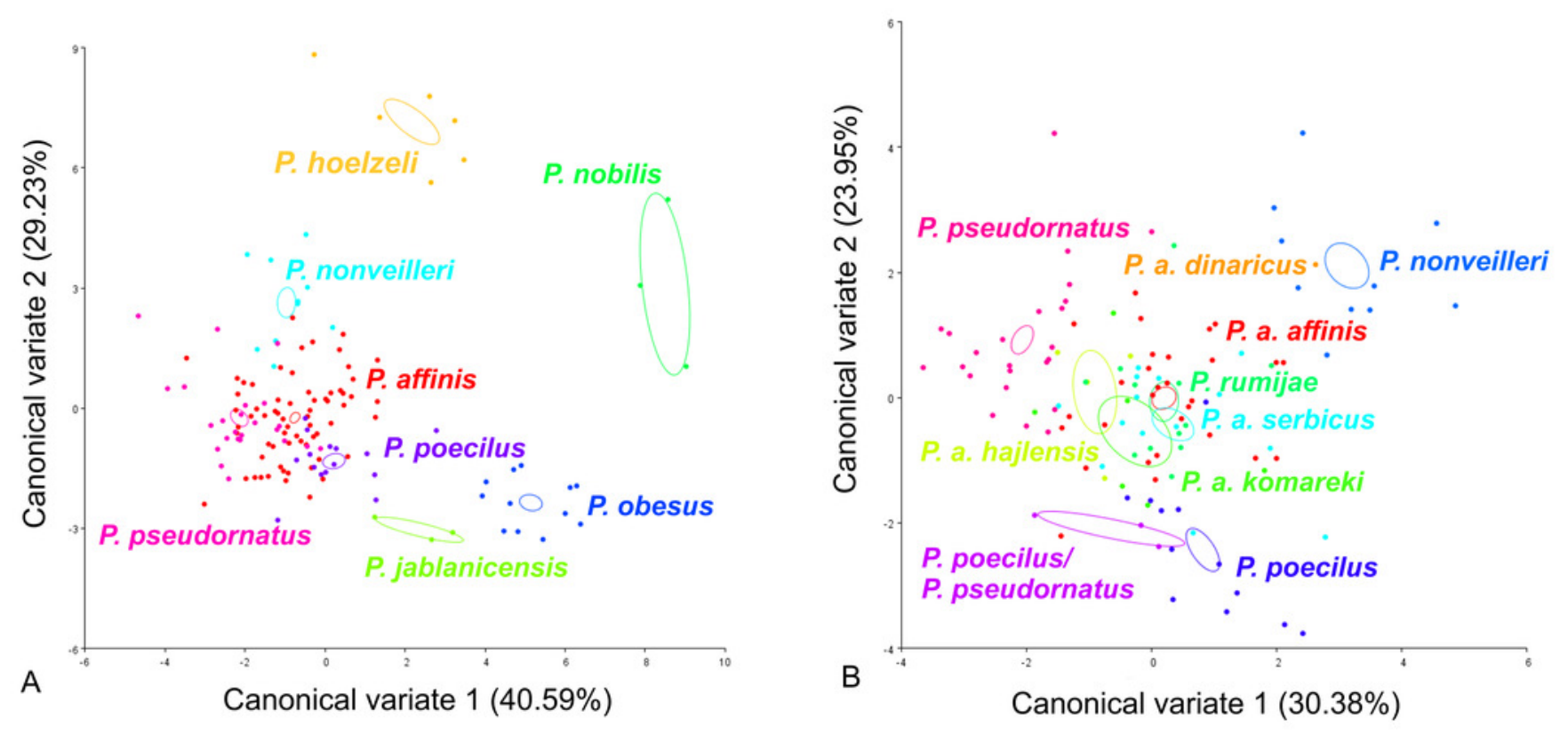
Figure 6

Scatter plot of the two first canonical variate axes (CV1 and CV2) analysis of centroid sizes of pronotum: $P$. ornatus group (A) and $P$. affinis complex (B).

The different colors indicate different species/subspecies of the studied bush-crickets.
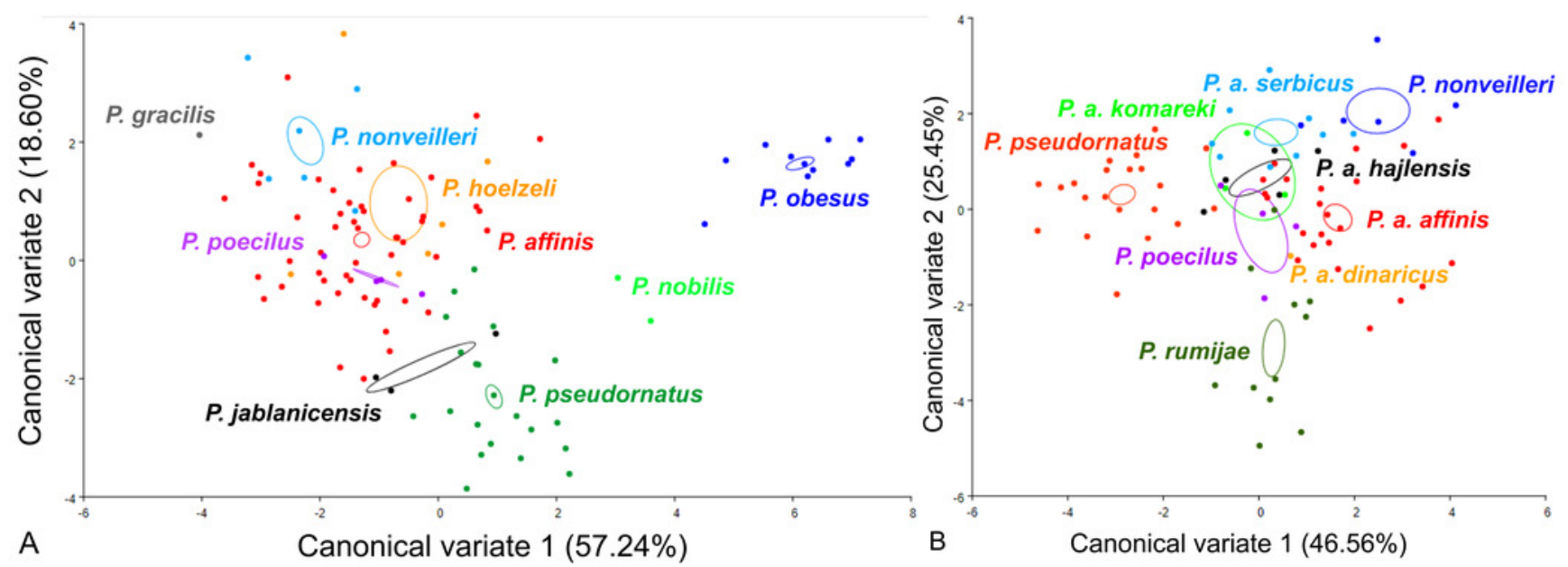
Figure 7

Principal Component Analysis (PCA) of stridulatory measurements and number of teeth: P. ornatus group.

The different colors indicate different species/subspecies of studied bush-crickets.

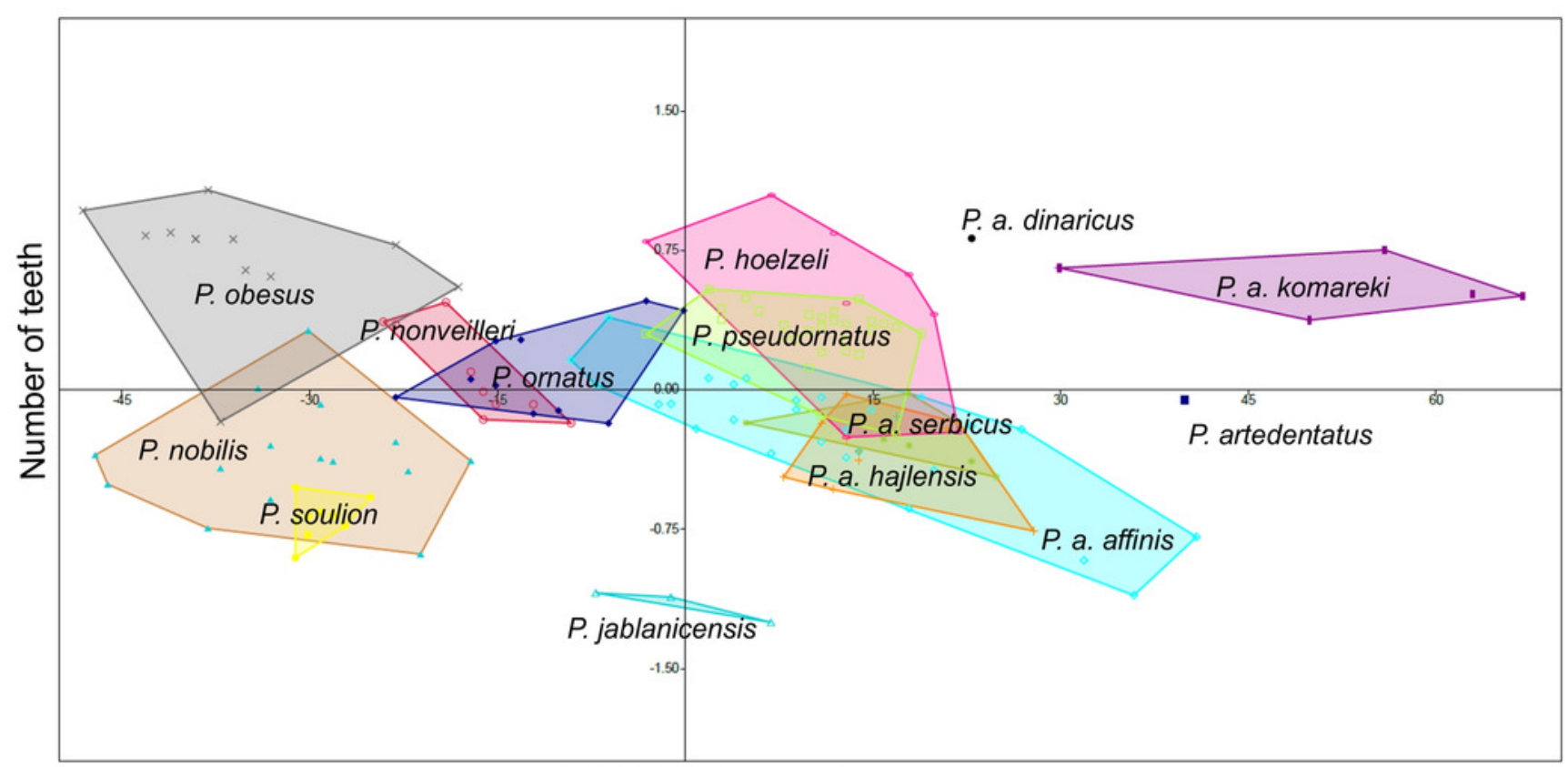

Stridulatory file lenght 
Figure 8

Phylogenetic tree based on Bayesian inference method including $\mathrm{CO}$ sequences of the $P$. affinis complex.

Bayesian Inference (BI) and Maximum Likelihood (ML) topologies were similar, so only one tree is shown. BI posterior probability $(>0.5)$ and $M L$ bootstrap values $(>50)$ are shown on the nodes. Pink indicates species outside of the $P$. affinis complex; blue indicates taxa from the designated $P$. affinis complex.

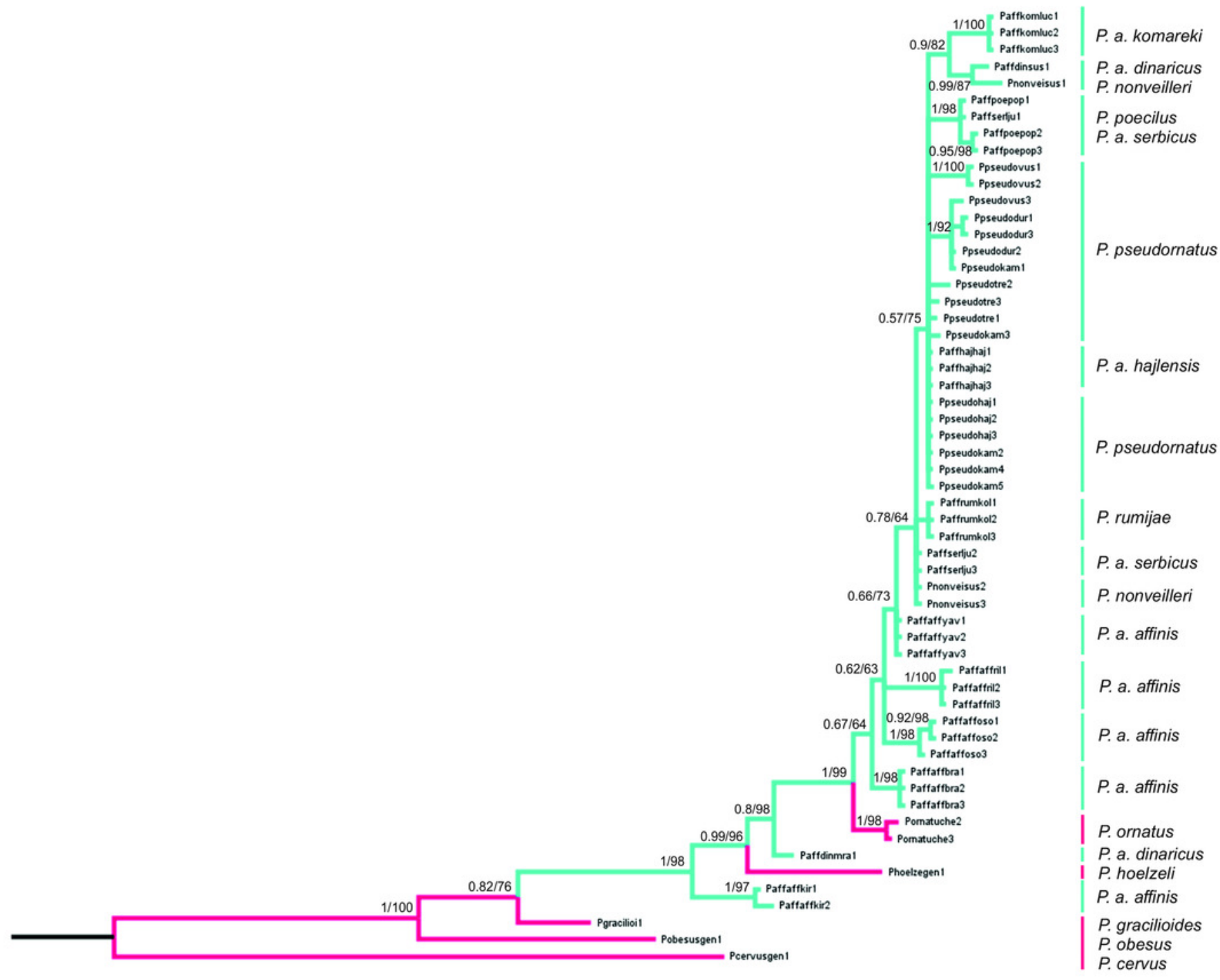




\section{Table $\mathbf{1}$ (on next page)}

The number of specimens used for the geometric morphometric analysis. 
1 Table 1:

2 The number of specimens used for the geometric morphometric analysis.

3

\begin{tabular}{|c|c|c|c|c|}
\hline Species & $\begin{array}{l}\text { Male } \\
\text { cercus }\end{array}$ & Tegmen & Ovipositor & Pronotum \\
\hline $\begin{array}{l}\text { Poecilimon affinis affinis* } \\
\text { (Frivaldszky, 1868) }\end{array}$ & 29 & 26 & 11 & 23 \\
\hline $\begin{array}{l}\text { Poecilimon affinis komareki* } \\
\text { Cejchan, } 1957\end{array}$ & 6 & 3 & 3 & 3 \\
\hline $\begin{array}{l}\text { Poecilimon affinis dinaricus* } \\
\text { Ingrisch \& Pavićević, } 2010\end{array}$ & 1 & 1 & 1 & 1 \\
\hline $\begin{array}{l}\text { Poecilimon affinis serbicus* } \\
\text { Karaman, } 1974\end{array}$ & 14 & 14 & 5 & 9 \\
\hline $\begin{array}{l}\text { Poecilimon affinis hajlensis* } \\
\text { Karaman, } 1974\end{array}$ & 4 & 6 & 2 & 5 \\
\hline $\begin{array}{l}\text { Poecilimon affinis poecilus* } \\
\text { Ramme, } 1951\end{array}$ & 15 & 12 & 5 & 4 \\
\hline $\begin{array}{l}\text { Poecilimon rumijae* } \\
\text { Karaman, } 1972\end{array}$ & 12 & 12 & 2 & 11 \\
\hline $\begin{array}{l}\text { Poecilimon nonveilleri* } \\
\text { Ingrisch \& Pavićević, } 2010\end{array}$ & 10 & 10 & 1 & 6 \\
\hline $\begin{array}{l}\text { Poecilimon pseudornatus* } \\
\text { Ingrisch \& Pavićević, } 2010\end{array}$ & 24 & 26 & 10 & 21 \\
\hline $\begin{array}{l}\text { Poecilimon hoelzeli } \\
\text { Harz, } 1966\end{array}$ & 6 & 6 & 3 & 6 \\
\hline $\begin{array}{l}\text { Poecilimon jablanicensis } \\
\text { Chobanov \& Heller, } 2010\end{array}$ & 3 & 3 & 1 & 3 \\
\hline $\begin{array}{l}\text { Poecilimon nobilis } \\
\text { Brunner von Wattenwyl, } 1878\end{array}$ & 3 & 3 & 2 & 2 \\
\hline $\begin{array}{l}\text { Poecilimon obesus } \\
\text { Brunner von Wattenwyl, } 1878\end{array}$ & 12 & 8 & 3 & 11 \\
\hline $\begin{array}{l}\text { Poecilimon gracilis } \\
\text { (Fieber, 1853) }\end{array}$ & - & - & 1 & 1 \\
\hline $\begin{array}{l}\text { Poecilimon artedentatus } \\
\text { Heller, } 1984\end{array}$ & - & - & 2 & - \\
\hline
\end{tabular}

4 *-Poecilimon affinis complex 


\section{Table 2 (on next page)}

List of the landmarks and semilandmarks of the pronotum, male cercus, tegmen, and ovipositor used in the geometric morphometric analysis. 


\section{Table 2:}

2 List of the landmarks and semilandmarks of the pronotum, male cercus, tegmen, and ovipositor 3 used in the geometric morphometric analysis.

\begin{tabular}{|c|c|c|c|c|}
\hline $\begin{array}{c}\text { The landmark } \\
\text { number }\end{array}$ & Pronotum & Male cercus & Tegmen & Ovipositor \\
\hline 1 & upper frontal part & groove left at base & most distant point & $\begin{array}{c}\text { highest point at the } \\
\text { base }\end{array}$ \\
\hline 2 & $\begin{array}{l}\text { upper part of mid } \\
\text { groove }\end{array}$ & groove right at base & $\begin{array}{c}\text { upper concave } \\
\text { point }\end{array}$ & $\begin{array}{c}\text { lowest point of the } \\
\text { base }\end{array}$ \\
\hline 3 & $\begin{array}{l}\text { upper posterior } \\
\text { point }\end{array}$ & $\begin{array}{l}\text { most distant point } \\
\text { at apex }\end{array}$ & most distant point & $\begin{array}{l}\text { begging of teeth at } \\
\text { the upper valve }\end{array}$ \\
\hline 4 & $\begin{array}{l}\text { lateral posterior } \\
\text { point }\end{array}$ & opposite to $3 *$ & most distant point & tip of upper valve \\
\hline 5 & lower frontal part & $\begin{array}{l}\text { middle measured } \\
\text { approximately } \\
\text { between } 4 \text { and } 2 *\end{array}$ & concave side point & $\begin{array}{l}\text { begging of teeth at } \\
\text { the lower valve }\end{array}$ \\
\hline 6 & lowest middle part & opposite to $5^{*}$ & most distant point & $\begin{array}{l}\text { middle between } 1 \\
\text { and } 3^{*}\end{array}$ \\
\hline 7 & $\begin{array}{l}\text { mid point between } \\
4 \text { and } 6^{*}\end{array}$ & $\begin{array}{c}\text { approximetly } \\
\text { middle between } 2 \\
\text { and } 5^{*}\end{array}$ & most distant point & $\begin{array}{l}\text { middle between } 2 \\
\text { and } 5^{*}\end{array}$ \\
\hline 8 & $\begin{array}{l}\text { begging of dark } \\
\text { band }\end{array}$ & $\begin{array}{c}\text { approximetly } \\
\text { middle between } 1 \\
\text { and } 6^{*}\end{array}$ & $\begin{array}{l}\text { most distant point } \\
\text { of the lateral vein }\end{array}$ & $\begin{array}{l}\text { upper point of } \\
\text { gonangulum }\end{array}$ \\
\hline 9 & & $\begin{array}{c}\text { approximetly } \\
\text { middle between } 5 \\
\text { and } 4^{*}\end{array}$ & $\begin{array}{c}\text { bifurcation between } \\
\text { veins }\end{array}$ & $\begin{array}{l}\text { lower point of } \\
\text { gonangulum }\end{array}$ \\
\hline 10 & & $\begin{array}{c}\text { approximetly } \\
\text { middle between } 6 \\
\text { and } 3 *\end{array}$ & $\begin{array}{c}\text { bifurcation between } \\
\text { veins }\end{array}$ & \\
\hline 11 & & $\begin{array}{l}\text { upper end of black } \\
\text { spine }\end{array}$ & $\begin{array}{c}\text { bifurcation between } \\
\text { veins }\end{array}$ & \\
\hline 12 & & $\begin{array}{l}\text { lower end of black } \\
\text { spine }\end{array}$ & $\begin{array}{c}\text { bifurcation between } \\
\text { veins }\end{array}$ & \\
\hline 13 & & tip of cercus & $\begin{array}{c}\text { mark on the } \\
\text { stridulatory vein } \\
\text { between the points } \\
3 \text { and } 10^{*}\end{array}$ & \\
\hline
\end{tabular}




\section{Table 3 (on next page)}

Measurements for stridulatory files of $P$. ornatus group. Measurements are given in $\mathrm{mm}$ : first row - Min-Max values. in brackets - avarage \pm Standard deviation.

Measurements are given in mm: first row - Min-Max values. in brackets - avarage \pm Standard deviation. 
1 Table 3:

2 Measurements for stridulatory files of the P. ornatus group. Measurements are given in mm: first 3 row - Min-Max values. in brackets - avarage \pm Standard deviation.

4

\begin{tabular}{|c|c|c|c|}
\hline Species & $\begin{array}{l}\text { Number of } \\
\text { specimens }\end{array}$ & $\begin{array}{l}\text { Stridulatory } \\
\text { length }\end{array}$ & $\begin{array}{l}\text { Number of stridulatory } \\
\text { teeth }\end{array}$ \\
\hline P. affinis & 9 & $\begin{array}{c}3.68-4.46 \\
(4.08)\end{array}$ & $\begin{array}{c}122-169 \\
(146)\end{array}$ \\
\hline P. affinis affinis & 24 & $\begin{array}{c}3.84-4.46 \\
(4.17 \pm 0.19)\end{array}$ & $\begin{array}{c}119-151 \\
(138 \pm 12)\end{array}$ \\
\hline P. affinis hajlensis & 7 & $\begin{array}{c}4.08-4.46 \\
(4.38 \pm 0.14)\end{array}$ & $\begin{array}{l}133-153 \\
(149 \pm 7)\end{array}$ \\
\hline P. affinis komareki & 5 & $\begin{array}{c}5.34-5.88 \\
(5.64 \pm 0.25)\end{array}$ & $\begin{array}{c}158-195 \\
(181 \pm 15)\end{array}$ \\
\hline P. affinis serbicus & 12 & $\begin{array}{c}3.84-4.37 \\
(4.14 \pm 0.21)\end{array}$ & $\begin{array}{l}136-156 \\
(144 \pm 6)\end{array}$ \\
\hline P. hoelzeli & 8 & $\begin{array}{c}4.14-5.34 \\
(4.85 \pm 0.42)\end{array}$ & $\begin{array}{l}125-150 \\
(141 \pm 8)\end{array}$ \\
\hline P. jablanicensis & 3 & $\begin{array}{c}2.96-3.04 \\
(3.01 \pm 0.05)\end{array}$ & $\begin{array}{l}121-135 \\
(128 \pm 7)\end{array}$ \\
\hline P. nobilis & 15 & $\begin{array}{c}2.78-3.98 \\
(3.28 \pm 0.33)\end{array}$ & $\begin{array}{l}81-111 \\
(97 \pm 9)\end{array}$ \\
\hline P. nonveilleri & 10 & $\begin{array}{c}3.74-4.32 \\
(3.97 \pm 0.18)\end{array}$ & $\begin{array}{l}104-119 \\
(111 \pm 5)\end{array}$ \\
\hline P. obesus & 12 & $\begin{array}{c}3.37-4.6 \\
(4.28 \pm 0.31)\end{array}$ & $\begin{array}{l}80-110 \\
(92 \pm 8)\end{array}$ \\
\hline P. ornatus & 10 & $\begin{array}{c}3.74-4.6 \\
(4.08 \pm 0.31)\end{array}$ & $\begin{array}{l}105-128 \\
(117 \pm 7)\end{array}$ \\
\hline P. pseudorantus & 29 & $\begin{array}{c}4.22-4.9 \\
(4.66 \pm 0.16)\end{array}$ & $\begin{array}{l}125-147 \\
(139 \pm 5)\end{array}$ \\
\hline P. soulion & 8 & $\begin{array}{c}2.74-3.17 \\
(2.99 \pm 0.13)\end{array}$ & $\begin{array}{l}97-103 \\
(99 \pm 2)\end{array}$ \\
\hline P. affinis dinaricus & 1 & 5.38 & 149 \\
\hline$P$. artedentatus & 1 & 4.8 & 168 \\
\hline
\end{tabular}

5

6 